\title{
Influence of Nitrogen treatments on Grain Yield, Yield Components and Grain Quality of Some Egyption Rice Cultivars.
}

\author{
Khaled M.H. Abd EI Salam and Medhat A.E. El-Dalil \\ Rice Technology Training Center (RTTC), Field Crops Research Institute, Agricultural \\ Research Center, Alexandria, Egypt
}

\begin{abstract}
Two field experiments were conducted at the Experimental Farm of Etai El- Baroud Agricultural Research Station, Behaira Governorate, Agriculture Research Center (ARC), Egypt during 2015 and 2016 summer seasons to evaluate the performance of three rice cultivars namely Giza 179, Sakha 105 and Sakha 106. A split plot design with three replicates was used. The main plots were devoted to rice cultivars and the sub plots were occupied by different nitrogen treatments $T_{1}(60$ $\mathrm{Kg} \mathrm{N} / \mathrm{fed}), \mathrm{T}_{2}(2$ Tons rice husk $+40 \mathrm{Kg} \mathrm{N} / \mathrm{fed}), \mathrm{T}_{3}(2$ tons rice husk +2 tons rice straw $+40 \mathrm{Kg} \mathrm{N} / \mathrm{fed})$ and $\mathrm{T}_{4}(2$ tons rice straw $+40 \mathrm{Kg} \mathrm{N} / \mathrm{fed}$ ). The results showed significant differences between cultivars for most studied characters. Comparison between means showed that in both study seasons rice cultivar Giza 179 gave the highest values for number of panicles $/ \mathrm{m}^{2}$, grain yield, broken and grain shape while, lowest values for 1000 grain weight, hulling, grain length, grain width and protein content. Moreover, Sakha 105 rice cultivar showed highest values for grain length, grain width, protein content $\%$ and water uptake. Sakha 106 rice cultivar showed superiority for 1000 grain weight, hulling and milling. Furthermore, applying 2 ton rice husk +2 ton rice straw $+40 \mathrm{Kg} \mathrm{N} /$ fed showed superiority for number of panicles $/ \mathrm{m}^{2}$, number of filled grains/panicle, 1000 grain weight, grain yield, hulling, milling and protein content. Interaction between rice cultivars and nitrogen treatments in both study seasons showed the highest values for number of panicles $/ \mathrm{m}^{2}$, grain yield and milling were noticed with Giza 179 rice cultivar and applying 2 tons rice husk +2 tons rice straw $+40 \mathrm{Kg} \mathrm{N} / \mathrm{fed}$. Moreover, the highest values for number of filled grains/panicle, 1000 grain weight and hulling were recognized with Sakha 106 rice cultivar and applying 2 tons rice husk +2 tons rice straw $+40 \mathrm{Kg} \mathrm{N} /$ fed.
\end{abstract}

Key words: Rice, grain quality, rice cultivars, nitrogen, fertilization, yield, organic, husk, straw.

\section{Introduction}

In Egypt approximately 6 million feddan of land are used for growing crops. This area is doubled because of the crop intensification and rotation used for summer (rice) and winter (wheat) crops. Increasing productivity per feddan is one of most important target for Egyptian economy. Rice straw residue is removed by grazing and mostly by burning. This practice causes many problems; firstly it causes air pollution which affects the health of human beings, secondly, it kills the macro and micro- organisms of the soil which convert the energy and nutrients from crop residues and thirdly, it produces some toxic gases and maximizes densification of soil layers. Although there is other economical ways to get rid of it as incorporation into the soil as a source of organic matter and save some nitrogen fertilizer. Rice husk represent about $20 \%$ of the weight of the harvest, paddy during refining processes, it has a little commercial value, because of their high silicon content. Incorporation of rice husk and rice straw into soil mixtures was found to affect the yield of many crops. Some studies indicated that $\mathrm{N}$-fertilizer cause pollution of the environment but nitrogen fertilization is applied of the crop during the early growth stages and accumulated in the vegetative parts to be utilized of grain formation. Also nitrogen fertilization has a vital role in nitrogen $\%$ in rice grains and nitrogen uptake by rice plants Salem et al. (2005). Also, Zhou et al. (2003) reported that the nitrogen uptake by rice and system productivity increased with the long-term combination between organic and chemical NPK fertilizer. Moreover, utilization of biological $\mathrm{N}_{2}$ fixation (BNF) can decrease the application of mineral $\mathrm{N}$ fertilizers, thus reducing environmental risks (Raimam et al., 2007 and Radwan et al. 2008).

Applying rice husk at rate 4 tha with $40 \mathrm{~kg}$ $\mathrm{N} /$ ha as urea incorporated into the dry soil during land preparation after wheat significantly increased shoot length, 1000 grain weight, grain and straw yields and milling\% while, $3 \mathrm{t} / \mathrm{ha}$ was adequate for the highest root depth, number of panicle/hill, panicle weight, grain yield, harvest index, hulling $\%$ and head rice $\%$. Soil organic matter content is gradually 
decline due to high cropping intensity which causes quick decomposition of organic matter Ebaid et al. (2004). Significant effects on most root, shoot, yield and its attributes, yield related, and panicle characters due to increasing husk rates from zero up to 4 tons/fed. 4 tons/fed gave the highest grain yield and its components, yield related, and panicle characters due to increasing husk rates from zero up to 4 tons/fed El -Dalil (2007).

The highest value of 1000 grains weight (20.94 g) was found with control. There was a highly significant effect on filled grain when rice straw plus nitrogen were added 3 weeks before transplanting, panicle length was significantly increased when 2 ton of rice straw plus $69 \mathrm{~kg}$ of nitrogen were applied. Addition of rice straw plus nitrogen 3 weeks before transplanting gave higher N-uptake than the other treatments. Nitrogen uptake was higher when rice straw was added alone directly before transplanting compared to control. Addition of rice straw plus nitrogen increased the phosphorus uptake. Organic matter was found to be higher with the application of rice straw than that with no straw. Using straw as a fertilizer reduces the environmental impact especially environmental pollution by nitrate and the products of burning Naiem (2006). However, the use value of organic matter decreased along with the organic resources continually increasing under the background of agriculture with high input, high output and high efficiency (Xi et al. 2004).

This study aimed to investigate the performance of some rice cultivars under different nitrogen treatments, including mineral, organic and their combinations, regarding some, yield and yield components and grain quality characters.

\section{Materials and methods}

Two field experiments were conducted at the Experimental Farm of Etai El- Baroud Agricultural Research Station, Behaira Governorate, Agriculture Research Center (ARC), Egypt during 2015 and 2016 summer seasons to evaluate the performance of three rice cultivars namely Giza 179, Sakha 105 and Sakha 106. A split plot design with three replicates was used. The main plots were devoted to rice cultivars and the sub plots were occupied by different nitrogen treatments $\mathrm{T}_{1}(60 \mathrm{Kg} \mathrm{N} / \mathrm{fed}), \mathrm{T}_{2}$
( 2 Tons rice husk $+40 \mathrm{Kg} \mathrm{N} / \mathrm{fed}$ ), $\mathrm{T}_{3}$ (2 tons rice husk +2 tons rice straw $+40 \mathrm{Kg} \mathrm{N} / \mathrm{fed})$ and $\mathrm{T}_{4}(2$ tons rice straw $+40 \mathrm{Kg} \mathrm{N} / \mathrm{fed}$ ).

During these successive seasons rice crop followed cultivation of wheat crop in the winter season and both rice and wheat were grown directly without tillage. In addition, the same experimental plot had been utilized at all seasons of study. Rice husk and chopped rice straw were used as organic fertilizers that were added before wheat cultivation in the first season only as top application, meanwhile, nitrogen source was urea added at 30 days after broadcasting. This amount was added in three splits; the first before broadcasting, the second at 30 days after broadcasting ( at the end of seedling stage and the beginning of tillering stage) and the third was applied after 60 days after broadcasting ( at the end of tillring stage and the beginning of panicle initiation). Sub plot size was $10 \mathrm{~m}^{2}$ and the sowing date in nursery was 10 May and plants were transplanted after 30 days after sowing to permanent field, in both seasons.

Soil samples were taken from experimental site at depth of $0-30 \mathrm{~cm}$ from soil surface. Soil analysis was conducted according to the methods of Black et al. (1965) was used. The experimental site soil had the following properties as an average of the two seasons: $\mathrm{PH}=7.5$, total organic matter $=1.5 \%$, total nitrogen $=0.27 \%$, available $\mathrm{P}=16.5 \mathrm{ppm}$ and available $\mathrm{K}=633.0 \mathrm{ppm}$.

At harvest, five meter square from central area of each plot were harvested for determination of grain yield then it was converted to tons/fed. Also, number of panicles $/ \mathrm{m}^{2}, 1000$ grain weight and number of filled grains / panicle were determined. The paddy rice samples were cleaned by Dockage Tester Machine (Carter Day CO, style number XT3, USA) to remove the dust foreign matter, mud balls, and immature green automatically. Rice samples (200 g for each) were taken randomly; samples were dehulled with an experimental Satake huller machine and polished in Satake miller. Furthermore, grain quality characters were recorded according to International Rice Research Institute (IRRI 1996). Analysis of variance was carried out according to Gomez and Gomez (1984) using SAS program, version 8.0. 


\section{Results and discussion}

\section{1- Effect of rice cultivars:}

Performance of the studied rice cultivars is presented in Tables (1, 2, 3 and 4). Data revealed that there were significant differences between rice cultivars for all studied characters except for amylose content \% in both study seasons. Comparison between means showed that rice cultivar Giza 179 gave the highest values for number of panicles $/ \mathrm{m}^{2}$ (386.5 and $414.6 \%$ ), grain yield (3.87 and 4.28 ton/fed), broken (12.89 and $12.55 \%)$ and grain shape (2.12 and 2.10 L/W) while, lowest values for 1000 grain weight (22.83 and $23.35 \mathrm{gm}$ ), hulling (79.27 and 79.74 $\%$ ), grain length (5.29 and $5.37 \mathrm{~mm}$ ), grain width $(2.50$ and $2.56 \mathrm{~mm})$ and protein content (7.60 and $7.85 \%$ ) in 2015 and 2016 seasons, respectively. Moreover, Sakha 105 rice cultivar showed highest values for grain length (5.71 and 5.65 $\mathrm{mm})$, grain width $(2.93$ and $2.86 \mathrm{~mm})$, protein content ( 8.12 and $8.46 \%)$ and water uptake (465.3 and $461.5 \mathrm{ml}$ water/100 gm milled grains) while, lowest values for number of filled grains/panicle (118.5 and 138.2), grain yield (3.41 and 4.00 ton/fed) and broken (5.44 and 5.21 \%) in 2015 and 2016 seasons, respectively. Furthermore, Sakha 106 rice cultivar showed superiority for 1000 grain weight $(25.72$ and $26.28 \mathrm{gm})$, hulling (80.26 and $80.83 \%$ ) and milling (71.20 and $71.29 \%$ ) while, lowest values for water uptake (451.8 and $449.5 \mathrm{ml}$ water/100 gm milled grains) in 2015 and 2016 seasons, respectively. Variation between rice cultivars might be due to genetic factors. These results were in harmony with (El-Feky 2006, El-Kalla et al. 2006, El-Sherif et al. 2007, El-Nory 2008 and Radwan et al. 2008, El Dalil 2011 and Abou ElSoud, 2015)

\section{2- Effect of nitrogen treatments:}

The primary goal of the present study was to reduce the application of mineral nitrogen in rice growing to lower production costs and reduce the adverse effects of chemical fertilizers on the environment. However the data presented in tables $(1,2,3$ and 4) showed that using different nitrogen treatments significantly affect most studied characters except for grain length, grain width, grain shape, amylose $\%$ and water uptake in both study seasons. Applying 2 ton rice husk +2 ton rice straw $+40 \mathrm{Kg} \mathrm{N} /$ fed showed superiority for number of panicles $/ \mathrm{m}^{2}$ (358.0 and 388.3), number of filled grains/panicle (139.7 and 158.9), 1000 grain weight (24.91 and $25.72 \mathrm{gm}$ ), grain yield (4.17 and 4.60 ton/fed), hulling (80.69 and $80.95 \%$ ), milling (71.42 and $71.78 \%$ ), protein content ( 8.20 and 8.42 $\%$ while, the lowest values for most previous characters were noticed by applying 2 ton husk +40 $\mathrm{Kg} \mathrm{N} /$ fed in 2015 and 2016 seasons, respectively. These results may led to the conclusion that adding husk and straw together to the soil caused improve in the soil texture which enhanced root growth and so caused successive improvement of soil drainage, which increased soil perculation and decreased the losses of nitrogen from the soil by denitrification which occurs under an aerobic condition of rice fields and in the other side it permited deeper penetration of plant root caused a significant improve in the growth of rice plants. Similar results were reported by (Ebaid et al. 2004, Gewaily 2006, Naiem 2006, Tabl 2008 and El Dalil 2011).

\section{3- Interaction between rice cultivars and different nitrogen treatments:}

Data in Tables (5 and 6) showed significant differences for interaction between rice cultivars and different nitrogen treatments for grain yield and its components and milling properties in both study seasons. The highest values for number of panicles $/ \mathrm{m}^{2}$ (422.6 and 460.5), grain yield (4.42 and 4.75 tons/fed) and milling (71.77 and $72.12 \%$ ) were noticed with Giza 179 rice cultivar and applying 2 tons rice husk +2 tons rice straw $+40 \mathrm{Kg}$ $\mathrm{N} /$ fed in 2015 and 2016 seasons, respectively. Moreover, the highest values for number of filled grains/panicle (147.2 and 163.1), 1000 grain weight (26.21 and $26.92 \mathrm{gm}$ ) and hulling (81.30 and 81.62 $\%)$ were recognized with Sakha 106 rice cultivar and applying 2 tons rice husk +2 tons rice straw $+40 \mathrm{Kg} \mathrm{N} / \mathrm{fed}$ in 2015 and 2016 seasons, respectively. Furthermore, the lowest values for broken (5.17 and 5.02\%) were noticed with Sakha 105 rice cultivar and applying 2 tons rice husk +2 tons rice straw $+40 \mathrm{Kg} \mathrm{N} /$ fed in both study seasons, respectively. These results were in harmony with 
those reported by (Ebaid et al. 2004 and El Dalil 2011).

Table (1): Mean values for grain yield and its components as affected by rice cultivars and nitrogen fertilization in 2015 and 2016 seasons.

\begin{tabular}{|c|c|c|c|c|c|c|c|c|}
\hline \multirow[t]{2}{*}{ Treatments } & \multicolumn{2}{|c|}{$\begin{array}{l}\text { Number of } \\
\text { panicles } / \mathbf{m}^{2}\end{array}$} & \multicolumn{2}{|c|}{$\begin{array}{l}\text { Number of filled } \\
\text { grains/panicle }\end{array}$} & \multicolumn{2}{|c|}{$\begin{array}{l}1000 \text { grain weight } \\
\text { (gm) }\end{array}$} & \multicolumn{2}{|c|}{$\begin{array}{l}\text { Grain yield } \\
\text { (ton/fed) }\end{array}$} \\
\hline & 2015 & 2016 & 2015 & 2016 & 2015 & 2016 & 2015 & 2016 \\
\hline \multicolumn{9}{|c|}{ C- (Cultivars) } \\
\hline Giza 179 & 386.5 & 414.6 & 130.5 & 145.9 & 22.83 & 23.35 & 3.87 & 4.28 \\
\hline Sakha 105 & 316.2 & 328.9 & 118.5 & 138.2 & 24.55 & 25.38 & 3.41 & 4.00 \\
\hline Sakha 106 & 306.1 & 335.4 & 132.2 & 141.1 & 25.72 & 26.28 & 3.66 & 4.19 \\
\hline L.S.D. 0.05 & 4.841 & 5.142 & 1.752 & 2.664 & 1.133 & 0.743 & 0.117 & 0.069 \\
\hline \multicolumn{9}{|c|}{ N- (Nitrogen treatments) } \\
\hline $\mathrm{T} 1$ & 342.7 & 358.9 & 129.1 & 146.6 & 24.45 & 25.04 & 3.83 & 4.25 \\
\hline $\mathrm{T} 2$ & 319.0 & 338.6 & 116.0 & 129.8 & 23.95 & 24.45 & 3.09 & 3.75 \\
\hline $\mathrm{T} 3$ & 358.0 & 388.3 & 139.7 & 158.9 & 24.91 & 25.72 & 4.17 & 4.60 \\
\hline $\mathrm{T} 4$ & 327.3 & 352.6 & 124.4 & 140.6 & 24.16 & 24.79 & 3.49 & 4.03 \\
\hline L.S.D. 0.05 & 6.511 & 4.873 & 4.325 & 5.346 & 0.155 & 0.223 & 0.211 & 0.184 \\
\hline \multicolumn{9}{|c|}{ Interaction } \\
\hline $\mathrm{C} \times \mathrm{N}$ & $* *$ & $* *$ & $* *$ & $* *$ & $* *$ & $* *$ & $* *$ & $* *$ \\
\hline
\end{tabular}

Table (2): Mean values for milling properties as affected by rice cultivars and nitrogen fertilization in 2015 and 2016 seasons.

\begin{tabular}{|c|c|c|c|c|c|c|}
\hline \multirow{2}{*}{ Treatments } & \multicolumn{2}{|c|}{ Hulling \% } & \multicolumn{2}{|c|}{ Milling \% } & \multicolumn{2}{|c|}{ Broken \% } \\
\hline & 2015 & 2016 & 2015 & 2016 & 2015 & 2016 \\
\hline \multicolumn{7}{|c|}{ C- (Cultivars) } \\
\hline Giza 179 & 79.27 & 79.74 & 70.33 & 71.24 & 12.89 & 12.55 \\
\hline Sakha 105 & 80.16 & 80.34 & 70.56 & 71.09 & 5.44 & 5.21 \\
\hline Sakha 106 & 80.26 & 80.83 & 71.20 & 71.29 & 6.45 & 5.65 \\
\hline L.S.D. ${ }_{0.05}$ & 0.078 & 0.296 & 0.117 & 0.033 & 0.698 & 0.334 \\
\hline \multicolumn{7}{|c|}{ N- (Nitrogen treatments) } \\
\hline $\mathrm{T} 1$ & 79.78 & 80.25 & 70.71 & 71.01 & 8.47 & 9.02 \\
\hline $\mathrm{T} 2$ & 79.58 & 80.14 & 70.18 & 70.79 & 8.30 & 7.78 \\
\hline $\mathrm{T} 3$ & 80.69 & 80.95 & 71.42 & 71.78 & 7.95 & 6.96 \\
\hline $\mathrm{T} 4$ & 79.53 & 79.87 & 70.47 & 71.23 & 8.33 & 7.44 \\
\hline L.S.D. ${ }_{0.05}$ & 0.178 & 0.104 & 0.280 & 0.311 & 0.105 & 0.295 \\
\hline \multicolumn{7}{|c|}{ Interaction } \\
\hline $\mathrm{C} \times \mathrm{N}$ & $* *$ & $* *$ & $* *$ & $* *$ & $* *$ & $* *$ \\
\hline
\end{tabular}


Table (3): Mean values for grain dimension properties as affected by rice cultivars and nitrogen fertilization in 2015 and 2016 seasons.

\begin{tabular}{|c|c|c|c|c|c|c|}
\hline \multirow{2}{*}{ Treatments } & \multicolumn{2}{|c|}{ Grain length (mm) } & \multicolumn{2}{|c|}{ Grain width (mm) } & \multicolumn{2}{|c|}{ Grain shape $(\mathrm{L} / \mathrm{W})$} \\
\hline & 2015 & 2016 & 2015 & 2016 & 2015 & 2016 \\
\hline \multicolumn{7}{|c|}{ C- (Cultivars) } \\
\hline Giza 179 & 5.29 & 5.37 & 2.50 & 2.56 & 2.12 & 2.10 \\
\hline Sakha 105 & 5.71 & 5.65 & 2.93 & 2.86 & 1.95 & 1.98 \\
\hline Sakha 106 & 5.53 & 5.45 & 2.75 & 2.81 & 2.01 & 1.94 \\
\hline L.S.D.0.05 & 0.139 & 0.065 & 0.133 & 0.041 & 0.045 & 0.022 \\
\hline \multicolumn{7}{|c|}{ N- (Nitrogen treatments) } \\
\hline $\mathrm{T} 1$ & 5.62 & 5.49 & 2.78 & 2.70 & 2.02 & 2.03 \\
\hline $\mathrm{T} 2$ & 5.47 & 5.59 & 2.73 & 2.76 & 2.00 & 2.04 \\
\hline $\mathrm{T} 3$ & 5.46 & 5.53 & 2.70 & 2.81 & 2.02 & 1.97 \\
\hline $\mathrm{T} 4$ & 5.49 & 5.56 & 2.69 & 2.73 & 2.04 & 2.02 \\
\hline L.S.D. 0.05 & n.s & n.s & n.s & n.s & n.s & n.s \\
\hline \multicolumn{7}{|c|}{ Interaction } \\
\hline $\mathrm{C} \times \mathrm{N}$ & n.s & n.s & n.s & n.s & n.s & n.s \\
\hline
\end{tabular}

Table (4): Mean values for protein, amylose and water uptake as affected by rice cultivars and nitrogen fertilization in 2015 and 2016 seasons.

\begin{tabular}{|c|c|c|c|c|c|c|}
\hline \multirow[t]{2}{*}{ Treatments } & \multicolumn{2}{|c|}{ Protein content \% } & \multicolumn{2}{|c|}{ Amylose content \% } & \multicolumn{2}{|c|}{$\begin{array}{c}\text { Water uptake (ml } \\
\text { water } / \mathbf{1 0 0} \text { gm milled } \\
\text { grains) }\end{array}$} \\
\hline & 2015 & 2016 & 2015 & 2016 & 2015 & 2016 \\
\hline \multicolumn{7}{|c|}{ C- (Cultivars) } \\
\hline Giza 179 & 7.60 & 7.85 & 19.19 & 19.07 & 460.6 & 456.3 \\
\hline Sakha 105 & 8.12 & 8.46 & 18.97 & 19.10 & 465.3 & 461.5 \\
\hline Sakha 106 & 7.77 & 8.07 & 19.08 & 19.02 & 451.8 & 449.5 \\
\hline L.S.D. 0.05 & 0.137 & 0.207 & n.s & n.s & 3.272 & 4.183 \\
\hline \multicolumn{7}{|c|}{$\mathbf{N}$ - (Nitrogen treatments) } \\
\hline $\mathrm{T} 1$ & 8.00 & 8.17 & 19.47 & 19.25 & 462.1 & 457.3 \\
\hline $\mathrm{T} 2$ & 7.62 & 7.83 & 18.61 & 18.30 & 456.0 & 450.5 \\
\hline $\mathrm{T} 3$ & 8.20 & 8.42 & 19.54 & 19.66 & 468.0 & 462.6 \\
\hline $\mathrm{T} 4$ & 7.47 & 8.08 & 18.70 & 19.05 & 450.8 & 452.7 \\
\hline L.S.D. 0.05 & 0.045 & 0.073 & n.s & n.s & n.s & n.s \\
\hline \multicolumn{7}{|c|}{ Interaction } \\
\hline $\mathrm{C} \times \mathrm{N}$ & n.s & n.s & n.s & n.s & n.s & n.s \\
\hline
\end{tabular}


Table (5): Mean values for grain yield and its components as affected by the interaction between rice cultivars and nitrogen fertilization in 2015 and 2016 seasons.

\begin{tabular}{|c|c|c|c|c|c|c|c|c|c|}
\hline \multirow[t]{2}{*}{ Cultivars } & \multirow[t]{2}{*}{$\begin{array}{l}\text { (Nitrogen } \\
\text { treatments) }\end{array}$} & \multicolumn{2}{|c|}{$\begin{array}{l}\text { Number of } \\
\text { panicles } / \mathbf{m}^{2}\end{array}$} & \multicolumn{2}{|c|}{$\begin{array}{c}\text { Number of } \\
\text { filled grains/ } \\
\text { panicle }\end{array}$} & \multicolumn{2}{|c|}{$\begin{array}{c}1000 \text { grain } \\
\text { weight }(\mathrm{gm})\end{array}$} & \multicolumn{2}{|c|}{$\begin{array}{c}\text { Grain yield } \\
\text { (ton/fed) }\end{array}$} \\
\hline & & 2015 & 2016 & 2015 & 2016 & 2015 & 2016 & 2015 & 2016 \\
\hline \multirow[t]{4}{*}{ Giza 179} & $\mathrm{~T} 1$ & 395.7 & 413.8 & 133.6 & 146.2 & 22.96 & 23.32 & 3.81 & 4.31 \\
\hline & $\mathrm{T} 2$ & 352.3 & 378.4 & 120.5 & 153.3 & 22.42 & 23.05 & 3.51 & 3.93 \\
\hline & $\mathrm{T} 3$ & 422.6 & 460.5 & 139.3 & 157.5 & 23.30 & 23.89 & 4.42 & 4.75 \\
\hline & $\mathrm{T} 4$ & 375.2 & 405.8 & 128.4 & 142.7 & 22.65 & 23.13 & 3.72 & 4.11 \\
\hline \multirow[t]{4}{*}{ Sakha 105} & $\mathrm{~T} 1$ & 316.2 & 330.5 & 123.1 & 141.3 & 24.57 & 25.50 & 3.72 & 4.12 \\
\hline & $\mathrm{T} 2$ & 310.5 & 317.2 & 105.2 & 119.5 & 24.10 & 24.56 & 2.73 & 3.57 \\
\hline & $\mathrm{T} 3$ & 330.8 & 342.3 & 132.5 & 156.2 & 25.22 & 26.35 & 3.95 & 4.45 \\
\hline & $\mathrm{T} 4$ & 307.1 & 325.4 & 113.3 & 135.7 & 24.32 & 25.10 & 3.22 & 3.87 \\
\hline \multirow[t]{4}{*}{ Sakha 106} & $\mathrm{~T} 1$ & 316.2 & 332.5 & 130.6 & 150.2 & 25.82 & 26.30 & 3.95 & 4.32 \\
\hline & $\mathrm{T} 2$ & 294.2 & 320.3 & 122.3 & 134.7 & 25.33 & 25.75 & 3.03 & 3.76 \\
\hline & $\mathrm{T} 3$ & 320.6 & 362.1 & 147.2 & 163.1 & 26.21 & 26.92 & 4.15 & 4.59 \\
\hline & $\mathrm{T} 4$ & 299.5 & 326.5 & 128.6 & 143.5 & 25.50 & 26.14 & 3.52 & 4.10 \\
\hline \multicolumn{2}{|c|}{ L.S.D. 0.05} & 5.017 & 4.523 & 3.551 & 3.142 & 0.314 & 0.251 & 0.081 & 0.124 \\
\hline
\end{tabular}

Table (6): Mean values for milling properties as affected by the interaction between rice cultivars and nitrogen fertilization in 2015 and 2016 seasons.

\begin{tabular}{|c|c|c|c|c|c|c|c|}
\hline \multirow{2}{*}{ Cultivars } & \multirow{2}{*}{$\begin{array}{l}\text { Nitrogen } \\
\text { treatments }\end{array}$} & \multicolumn{2}{|c|}{ Hulling \% } & \multicolumn{2}{|c|}{ Milling \% } & \multicolumn{2}{|c|}{ Broken \% } \\
\hline & & 2015 & 2016 & 2015 & 2016 & 2015 & 2016 \\
\hline \multirow[t]{4}{*}{ Giza 179} & $\mathrm{~T} 1$ & 79.43 & 80.12 & 70.73 & 71.33 & 13.26 & 15.62 \\
\hline & $\mathrm{T} 2$ & 78.90 & 79.33 & 69.20 & 70.52 & 13.02 & 12.36 \\
\hline & $\mathrm{T} 3$ & 80.23 & 80.56 & 71.77 & 72.12 & 12.57 & 10.71 \\
\hline & $\mathrm{T} 4$ & 78.50 & 78.96 & 69.60 & 70.98 & 12.72 & 11.51 \\
\hline \multirow[t]{4}{*}{ Sakha 105} & $\mathrm{~T} 1$ & 79.90 & 80.10 & 70.27 & 70.96 & 5.82 & 5.39 \\
\hline & $\mathrm{T} 2$ & 80.00 & 80.22 & 70.17 & 70.52 & 5.31 & 5.16 \\
\hline & $\mathrm{T} 3$ & 80.53 & 80.67 & 71.10 & 71.62 & 5.17 & 5.02 \\
\hline & $\mathrm{T} 4$ & 80.20 & 80.35 & 70.70 & 71.25 & 5.47 & 5.25 \\
\hline \multirow[t]{4}{*}{ Sakha 106} & $\mathrm{~T} 1$ & 80.00 & 80.52 & 71.13 & 70.75 & 6.33 & 6.05 \\
\hline & $\mathrm{T} 2$ & 79.83 & 80.87 & 71.17 & 71.33 & 6.56 & 5.83 \\
\hline & $\mathrm{T} 3$ & 81.30 & 81.62 & 71.40 & 71.61 & 6.10 & 5.16 \\
\hline & $\mathrm{T} 4$ & 79.90 & 80.31 & 71.10 & 71.46 & 6.79 & 5.57 \\
\hline \multicolumn{2}{|c|}{ L.S.D. ${ }_{0.05}$} & 0.308 & 0.211 & 0.302 & 0.259 & 0.215 & 0.117 \\
\hline
\end{tabular}




\section{Conclusion}

The present study indicated that applying 2 ton rice husk +2 ton rice straw $+40 \mathrm{Kg} \mathrm{N} / \mathrm{fed}$ showed superiority for number of panicles $/ \mathrm{m}^{2}$, number of filled grains/panicle, 1000 grain weight, grain yield, hulling, milling and protein content. Moreover, the interaction between rice cultivars and nitrogen treatments in both study seasons showed the highest values for number of panicles $/ \mathrm{m}^{2}$, grain yield and milling were noticed with Giza 179 rice cultivar and applying 2 tons rice husk +2 tons rice straw $+40 \mathrm{Kg} \mathrm{N} /$ fed. Moreover, the highest values for number of filled grains/panicle, 1000 grain weight and hulling were recognized with Sakha 106 rice cultivar and applying 2 tons rice husk +2 tons rice straw +40 $\mathrm{Kg} \mathrm{N} /$ fed.

\section{References}

Abou El-Soud G.M..2015. Effect of bio, organic and nitrogenous fertilization on the productivity of some rice cultivars (Oryza sativa, L). A thesis of ph.D. in agricultural sciences (agronomy), faculty of agriculture (Saba Basha), Alexandria University.

Black, L.A. ; D.D.Evan; L.E. Ensminger; J.L. White and E.Clark 1965. Methods of soil analysis. (Mmer Soc. Of Agrom. Inc., Publisher Madison, Wiscon Son, U.S.A.

Ebaid. R.A; A.A. El-Hissewy and M.El-Dalil. 2004. Preliminary study on utilization of rice husk in rice cultivation. Egypt. J.Agric. Res., 83(5B): 369-376.

El-Dalil,M.A. 2007. A study on the effects of soil application of rice husk and irrigation intervals on yield and grain quality of rice .M.Sc, thesis Al-Azhar university. Egypt.

El-Dalil,M.A. 2011. A study on the effects of soil application of rice husk and irrigation intervals on yield and grain quality of rice. A thesis of ph.D. in agricultural sciences (agronomy), faculty of agriculture (Saba Basha), Alexandria University.

El- Feky, K.A. (2006). Agricultural studies on rice crop. M.Sc. Thesis Fac. of Agric. Kafr El-Sheikh, Tanta Univ., Egypt.

El-Kalla, S.E., S.M. Said, A.M. Abdel-Rahman and A.M. Kisbk (2006). Response of rice cultivar to irrigation intervals and some organic fertilizer treatment in newly reclaimed soils J. Agric. Sci. Mansoura Univ. 31 (9) 547-555.

El-Nory, M.I. (2008). Effect of organic and nitrogen fertilizer on the performance of some rice cultivars under North Delta conditions. M.Sc. Thesis Fac. of Agric. Kafr El-Sheikh, Univ., Egypt.

El-Sherif, E., S.A. Ghanem, R. Sorour and A. Abdou Zadan (2007). Rice production under organic and inorganic fertilization. J. Agric. Sci. Mansoura Univ., 32 (3) 16111626.

Gewaily, E.EA. (2006). Behavior of some nutrient elements in rice soils under different irrigation intervals. Ph.D. Thesis, Fac. of Agric., Mansoura Univ., Egypt.

Gomez, K.A. and A.A. Gomez (1984). Statistical Procedures for Agricultural Research. An International Rice Research Institute Book. John Willey and Sons Inc., New York,U.S.A.

International Rice research Institute (IRRI) 1996. Standard Evaluation System for Rice. IRRI, Manila, Philippines. P52

Naiem, E. S. B. 2006. Availability of some nutrient elements in flooded rice soils fertilized with organic and mineral nitrogen fertilizers. Ph.D. Thesis, Fac. Agric. Mansoura Univ. Egypt.

Radwan, F.I., I. Abou- El- Seoud and A. Badr (2008). Response of two rice cultivar to blue grain green Algae, A mycorrhizae inoculation and mineral nitrogen fertilizer. J.of Plant Sci. and Biotechnology, 2 (1): 29-34.

Raimam, MP; U. Albino, M.F. Cruz, L. ovato, G.M. Spago, F. Ferracin, T.P. Lima, D.S. Goulart, T. Bernardi, C.M.Miyauchi, M. Nogueira, G. Andrade (2007). Interaction among free-living $\mathrm{N}$ - fixing bacteria isolated from Drosera villosa var. villosa and AM fungi (Glomus clarum) in rice (Oryza sativa L.). Applied Soil Ecology, 35(1):25-34.

Salem, A.k.M.;Zayed;A.G. Ahamed and A.A.Abou Khalifa 2005.Effect of nitrogen, 
potash levels and transplanting regularity on rice crop productivity. Egypt J. Agric. Res., 83, No.5 (b):449-457

SAS Institute. 1999. SAS System. Version 8. Statistical Analysis System Institute, Cary, NC, USA.

Tabl, D.M.M. (2008). Effect of nitrogenous and potash fertilization on productivity and grain quality of some rice cultivars. M.sc. Thesis Fac. of Agric. (Saba Basha) Alex. Univ.
Xi, Z.B., Y.Q. Wang and P.Z. Yang. 2004. The issue on organic manure in developing modern agriculture in China. Scientia Agricultura Sinica. 37: 1874-1878.

Zhou W.J., K.R. Wang, G.Y. Zhang (2003). Some effects of inorganic fertilizer and recycled crop nutrients on soil nitrogen supply and paddy rice production in the red earth region of China. Acta Ecologica Sinica, 23, 914-922.

\section{الماذص المرص}

 anرية}

\section{خالامصمطلف حمى عبد السلم ومدهت عبد المنم الللل}

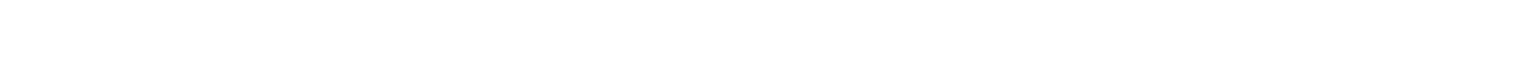

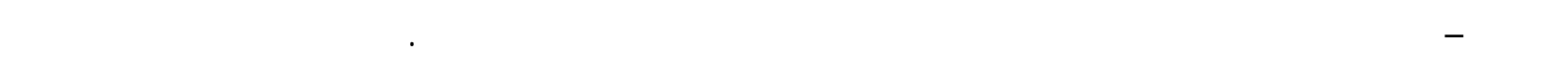

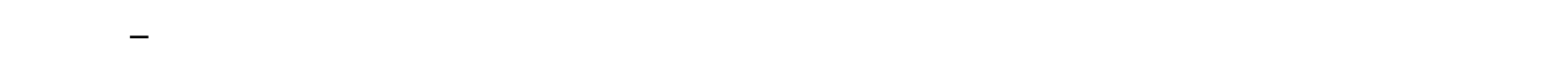

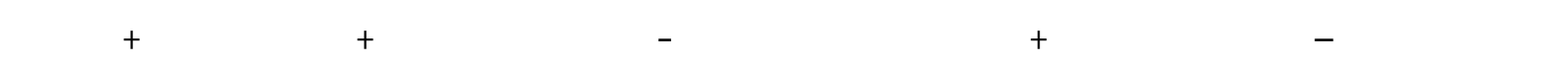

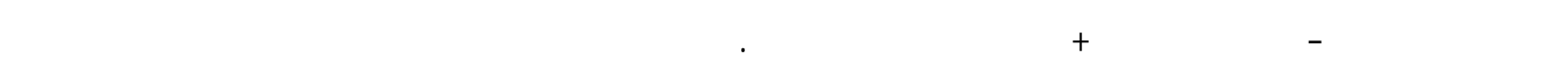

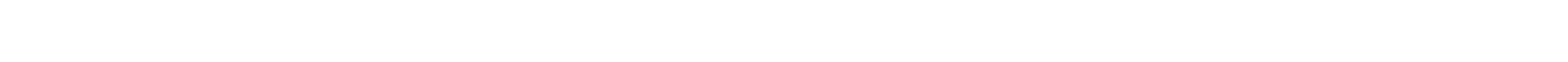

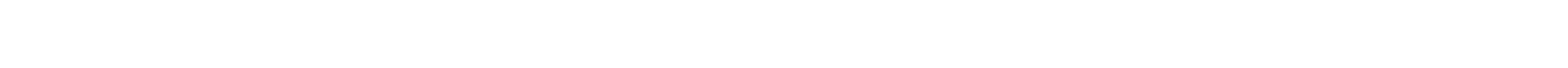

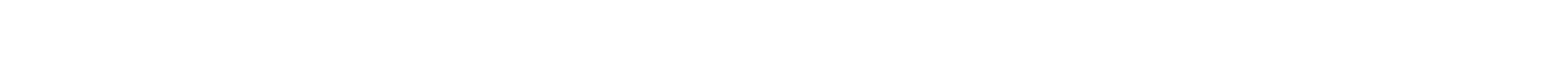

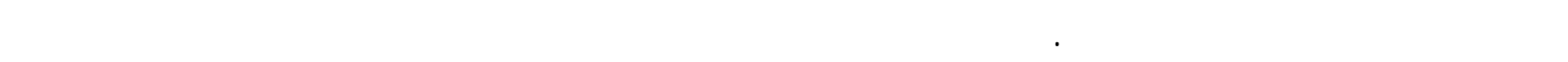

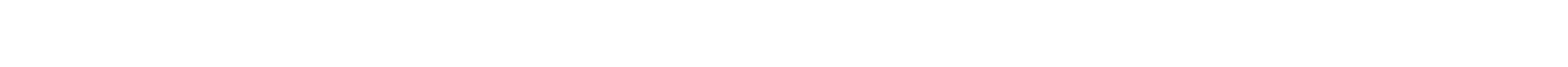

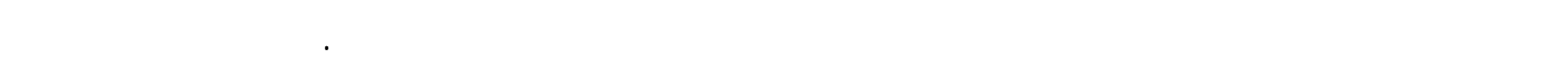

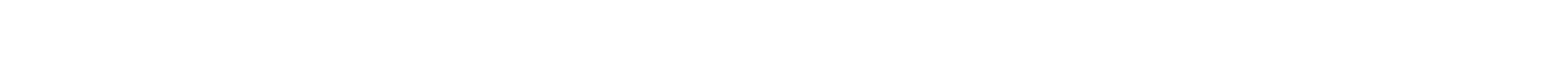

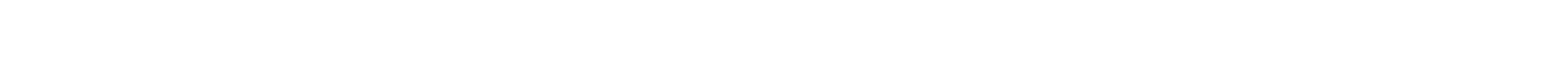

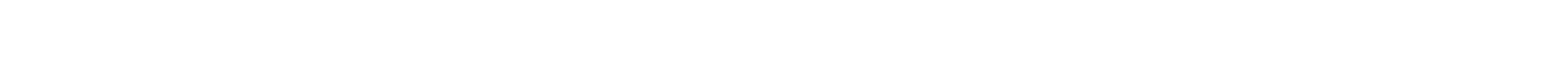

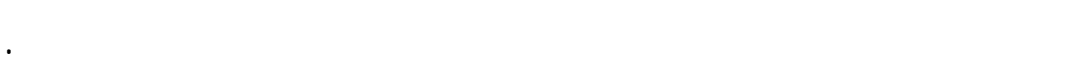

